\title{
The critical spirit of Alexandru I. Philippide: Un specialist român la Lipsca
}

\author{
Simona-Andreea Șova* \\ Faculty of Letters, "Alexandru Ioan Cuza" University, Bd. Carol I 11, 700506 Iaşi, Romania
}

\section{Article info}

History:

Received January 22, 2015

Accepted March 1, 2015

Published July 17, 2015

Key words:

Philippide

scientific polemic

diachrony

history of language

\begin{abstract}
Benefiting from the consequences of cultural and scientific development which kicked off in the $19^{\text {th }}$ century, the Romanian space also felt the lags up till then. The development and organisation deficit of science and culture, the poor quality of their relationships with the social complex, were augmented frequently not necessarily by the poor quality of the Romanian scholars, but by a certain superficiality of theirs in the approach and presentation of the treated matters. Trying to confer reliability, accuracy and transparency to the scientific construction in which he took part, A. Philippide often felt in a negative manner some of the scientific behaviours and results presented by his generation colleagues. In this context, beyond the high quality of his results and his highly responsible attitude, the way in which the scholar from Iași tried to improve the process was the scientific polemic.
\end{abstract}

\section{Preliminaries}

The period between the $19^{\text {th }}$ century and the first third of the $20^{\text {th }}$ century represented, at European level, a period of great development, almost explosive at a scientific, mentality and cultural level. The discoveries in various domains of natural sciences, the occurrence of new scientific theories, of new research methods and, especially, the capacity of scholars to see the entire effort as collaborative and relatively unitaryfruitful by assuming the same guiding principles and by the common use of methods and instrumentsbrought important and radical changes in science as well as at the level of culture and mentality. The debates that took place exceeded the previous rhythm, natural sciences and the methods with which they operated, generating not steps, but leaps and, based on this, progress possibilities. The conditions of movement and fructification of ideas in the European space were precisely the particularities and atmosphere which people themselves created in various spiritual spaces of Europe. Although researchers and thinkers of value got involved in the cultural-scientific transformations within the Romanian space, different factors prevented the moment to be used for the creation of a solid framework, favourable to the thorough reception of ideas and, eventually, to serve as basis for development, including at the level of the mass mentality. Although there existed individuals of an overwhelming erudition and who had a high awareness of the mission of the man of science and culture (such as Bogdan Petriceicu Hasdeu, Titu Maiorescu, Sextil Puşcariu, A. Philippide), their huge effort was not necessarily coordinated or correlated, neither in the direction of actual research, nor in that of developing social conscience. Offering either the example of the stroke of genius, or of their own tenacious striving, or of a combination of these two, they strived to change inertial thinking, mentality patterns and perspectives of the human destiny as social being and of the society as a structural-functional ensemble. The period "astride two centuries", as Sextil Pușcariu sees it, was one of idea struggle, of inner social torment, of the need to make order in the existing social-cultural chaos and to give a new direction to culture, by its relation and connection to the great European movements of the spirit.

*Email address: simona_sova@yahoo.com. 


\section{The Scholar}

Endowed with an exceptional analytical spirit, with a tireless thirst to get close to reality, in order to understand and present it, with a huge capacity to subject his own ideas and researches to all issues imposed by science, renouncing them, if they would turn out to be wrong-defining features of many hardworking geniuses, among which also Charles Darwin, whose On the Origin of Species appears in the year of A. Philippide's birth-, but also with an acuity of the critical spirit which almost always reached almost selfdestructive intransigence, A. Philippide, the great representative, along Garabet Ibrăileanu, of the critical spirit in Iasi and the creator of the School of Linguistics in Iași, is the one who will shed light on the Romanian linguistics, opening the door for true neo-grammarian research, based on neo-positivist philosophy and the scientism spirit of that time. Volcanic and excessive temper, of an exceptional erudition, A. Philippide detested superficiality, empty oratory, form without substance, that is why he believed that the contemporary society was flawed, and the political class inefficient, incompetent and indolent. Structured on the basis of polemic dialogue, his scientific works prove an unusual freedom of expression in rescinding the others-but also to appreciate their contribution to the development of the Romanian culture-, the criticism of the scholar from Iasi being oriented mainly on the Romanian and foreign intellectual (Bogdan Petriceicu Hasdeu, Sextil Pușcariu, Ovid Densusianu, Lazăr Șăineanu, Heimann Hariton Tiktin, Gustav Weigand, etc.), revealing the "realist linguist and the man of exemplary firmness in his respect for the cultural deontology" (Pamfil, 2008, p. 90).

\subsection{Preoccupation directions reflected in some of the writings}

Dissatisfied by the scientific and cultural atmosphere of his time, when he was only 24 , in $1883^{1}$, A. Philippide decides to elaborate a study which reveals the young man eager to learn and affirm the truth, the lucid researcher, mature in supporting his arguments, the inflexible man on the way to truth, severe with himself and with his fellowmen, intransigent through the polemic of speech. Starting from the in-depth and critical study of the linguistic theories of Timotei Cipariu, B. P. Hasdeu and Alexandru Lambrior, he will elaborate the text Știința noastră, subtitled Cum știm. Cum ar trebui să știm. Starea psicologică. Ever since this first step, the Romanian scholar shows himself to be preoccupied by the method and by the instruments, by the extent in which these are integrated in a philosophy and guided by scientific principles: "I will try, hence, to fix the orders of truths, that a Romanian should look for when studying his mother tongue, and that are means with which he could achieve the aim of his scientific tendencies; I will decide compared to the ideal the real results of his struggles; and, at the end, I will establish the extent to which Romanian intelligence could come close to science" (Philippide, 2006) ${ }^{2}$. The focus of attention in this direction shows by itself the clear understanding of the manner in which an authentic and quality research should be carried out.

Closely following the path, A. Philippide understands that the discoveries of European scholars, although extremely valuable, are not sufficient to solve the problems of Romanian linguistics-whose solving was imperative - and that this process had to be produced by the effort of Romanian scholars. In this way, having not only linguistic knowledge and a philosophical perspective, but also a good command of the field and its needs, the great linguist understands the necessity to solve first certain actual problems which kept Romanian linguistics in suffering, laying, at the same, solid conceptual and principle foundations.

\footnotetext{
${ }^{1}$ Ivănescu (1984) specifies that A. Philippide’s study was drafted in 1885 (p. XI), but Andriescu (1983) thinks that "there is quite reliable evidence that these pages were written between the years 1883-1884. The name of Lambrior, dead in 1883, is quoted every time without being accompanied by the word «mister», as is done with living authors, and the last bibliographic information is from (Tiktin, Studien zur rumänischen Philologie). As A. Philippide was acquainted with all that was published, making the necessary specifications carefully, there is no doubt left that this study couldn't be written later than the mentioned year" (p. 7).

${ }^{2}$ The citation fully respects the author's text as it appears in the mentioned edition.
} 
In 1897, Gramatica elementară a limbii române appears, published as a necessity, as the author confesses in the foreword, because the information comprised in the grammars of that time were not in the least satisfactory: "For the history of the Romanian language, which I set to publish... we needed a Romanian grammar, where one can find the forms of the common language catalogued, the meanings of these forms and numerous examples. But none of the previous grammars could do me any service, because, making abstraction of the fact that forms are found either falsely, or scarcely, or without a systemic enumeration, the examples are utterly insufficient: for the skeleton of a form three or four words are given as examples and then an etcetera, and for the meaning of the forms-in the study of which in fact our grammarians copied only the schematics of foreign rational grammars, French or German-they give, under the pretext of pedagogy, pieces of reading, from which, supposedly, the student should choose those necessary" (Iordan, 1978, p. 80). Without becoming a fundamental work of the Romanian grammar, A. Philippide's Gramatica remains a benchmark by its rich illustrative material for the morphological categories in our language, as well as by the clarity of the basic concept. The most important thing, however, refers to the basic purpose of this writing, clarifying the author on certain issues, being, namely, an instrument within a wider endeavour, indispensable to certain development stages of science.

The specialization in Germany (1888-1889) familiarizes A. Philippide with the thinking of the Neogrammarian School, dominated during that time by its very founders, through the outlooks of Hermann Osthoff and Karl Brugmann, laid out in the work Morphologische Untersuchungen. I. Teil, published in 1878, Germany, and considered the manifest of this school, as Ivănescu (1984) shows: "In 1894 no other current dominated the Romanic linguistics than the neo-grammarian one, which Philippide knew right from the source" (p. XV). Being in accordance, in a structural-organic manner, with the spirit of the neogrammarians, A. Philippide publishes in 1894 Principii de istoria limbii, adaptation with numerous personal contributions of Hermann Paul's book, Prinzipien der Sprachgeschichte, 1882, named by Hermann Suchier the "Bible of the linguist". The work theorizes the causes and rules after which language changes, revealing in particular the influence of the psychological factor, and contributes to the reformation of the outlook about language, by the explanation and rich illustration of the causes the Romanian language changed throughout its existence ${ }^{3}$. Considering that language lives through the ones who speak it, fact which determines its evolution, A. Philippide follows the psychological factor of human language and explains the language changes through the need of the speakers to express themselves clearly and to understand one another. In this context, A. Philippide formulates three important principles of linguistic changes: convenience, clarification and regulation. Convenience presents developments such as sound sliding, analogy, contamination, immediate creation, isolation, mixture of speeches, rhythm etc. Through a psychological process which remains unknown to the interlocutor, to speaker strives to find the grammar forms and words most appropriate for what he wants to say. This fight produces effects on the language, by almost complete clarification of the relation between the idea content and its expression in actual words. Regulation represents the voluntary intervention of the individual in the language evolution and has two subdivisions, regulation in general and written language. It is noted that A. Philippide considered causes of the language ignored by $\mathrm{H}$. Paul, such as rhythm, will, thought evolution and differentiation, encountered in Humboldt and Steinthal, views known indirectly, through G. von Gabelentz. Furthermore, the idea that phonetic changes have their causes in the change of conformation and the evolution of the articulatory organs is in accordance with certain opinions of the era, present in Nigra and Osthoff, Schleicher, Ascoli and Schuchardt. The phrase "articulatory organs", encountered in Nigra and Osthoff, becomes at A. Philippide "base of articulation".

The monumental work Originea rominilor, fundamental for the Romanian and European linguistics (see Gafton, 2009), demonstrates the scientific work-power and the synthesis capacity of the linguist from Iasi, reason for which Iorgu Iordan considers it "a masterpiece of our philological literature (in the broadest

\footnotetext{
${ }^{3}$ The text appeared in Philippide (1894). The same editors (G. Ivănescu and Carmen-Gabriela Pamfil), accompanied by Luminița Botoșineanu, edit Istoria limbii române, appeared at Polirom Publishing House in 2011.
} 
sense of the word)" (Iordan, 1969, p. 111). A. Philippide's attempt doesn't consist in establishing the relation of derived languages with a primitive language, but in demonstrating that "in the languages' way of being, the ethnic kinship of the nations who speak them is manifested" (Philippide, 1928, p. 340). The first volume, Ce spun izvoarele istorice (1925), follows the formation of the Romanian people from a triple point of view, of the place, time and of its manner of forming. The two ways to solve the formulated problem are the historical one, by exhaustive consultation of written sources, and the linguistic one, by the study of Romanian language itself. In the second volume, Ce spun limbile română și albaneză (1928), dominated by the linguistic perspective, A. Philippide is interested both in the spreading on site of the Romanian dialects, analysis realized by a comparative study, as well as in the geographical aspect of the origin of the Romanian people and, to a certain extent, in the ethnological aspect ${ }^{4}$.

\section{The polemic attitude}

The effervescence and cultural-scientific openings of the period had brought to the surface various attitudes and tendencies by which the form was exaggerated intentionally, the substance being mimed, leaving the door opened to superficial behaviours. Given his thorough training of researcher, as well as the high consciousness of A. Philippide, he will develop a critical attitude towards some of the results of his contemporaries and their dissonant presentation. The situation was aggravated by two factors: a) that was a moment that needed all seriousness to pour the foundations of a new social, scientific and mentality construction; b) it was absolutely inacceptable that the temptation of success obtained in superficial manners conquered valuable scholars, whom A. Philippide respected, whose science he acknowledged, being models, whose self-exigency should have been much higher. Probably the stakes conjugated with circumstance generates the impetuous and merciless criticism of the scholar in Iasi.

\subsection{Theoretical delimitations}

The polemic, a particular form of conflict communication, indicates a verbal exchange, a group of at least two texts which are confronting and facing each other. Metaphorically, the polemic is a verbal war and the constitutive discourses are marked by liveliness, by an aggressive character which differentiates them from debate, but also from fight, which degenerates and leads to confrontation for the self, the contents being less important. In the case of scientific discourse, the polemic character is of a constitutive nature, considering that any new scientific theory can trigger a polemical debate in the intellectual area in which it occurred, that is why polemic can also be seen as a constitutive dimension of logos.

People of culture are involved in a controversy with a view to search for the truth, either with the purpose of bringing their contribution to the development of science, or to say the last word and obtain supremacy in a field of knowledge, polemic becoming "an exercise of the spirit through which a truth is discovered or stressed" (George, 1973, p. 61). Thus, in the case of a scientific polemic between two scholars, there shouldn't be a question of one loser and one winner, since their purpose is to disclose to the readers, either knowing or unknowing, the correctness and veracity of the debated information.

The polemic that confronts scientists may exceed the frontiers of the field where it was born and acquire a multidisciplinary character. It is a dialogued manifestation of the polemical phenomenon, based on dialogue and represents a type of conflict interaction in which two or more distinct speakers, whose discursive positions are opposed, face each other. Polemic exchange does not always occur face to face, being able to be conducted remotely, when an immediate verbal exchange can't take place. Thus, two discourses are confronted in polemic, of which one is the trigger, interpreted as aggressor and initiator of the polemic, and the other, reactive, mark of the actual debut of the polemic. Polemic is born at the level of reaction, when there is a dialogued crystallization of a conflict between two adverse positions, owed to a profound disagreement which puts its protagonists face to face. Since this is a real reaction,

\footnotetext{
${ }^{4}$ Originea romînilor knew its first reprinting only today, made by Roxana Vieru, at the University of Iași Publishing House, with volume I appearing in 2014, and the second volume scheduled to appear this year.
} 
dialogism is most often generated by an internal interaction with the interlocutor's discourse, case in which it presents itself in the form of "interlocutive dialogism" (Vlad, 2011, p. 201). In order to disqualify the new point of view, the speaker integrates it in his own discourse through the medium of a polemical resumption or anticipating a future intervention of his interlocutor, which he questions. This strategy is specific for "anticipatory interlocutive dialogism" (Vlad, 2011, p. 201), which allows us, equally, to anticipate a possible polemical reaction of the interlocutor, with the purpose of defusing it. Between the two polemicists there is an ethics of the intellectual endeavour, a style, some conduct rules which allow the development of a constructive polemic, beneficial for cultural progress: "As in any conversation, the interlocutors must speak the same language, at least for the main disputed elements. Adversaries who vociferate each in turn, and not in relation to the other, don't actually have a polemic" (George, 1973, p. 263). That is why a true polemic is the one that constitutes a reason for respect and closeness between the adversaries, related in terms of superior intellectuality.

\subsection{Philippide's polemic}

Clearly and early understanding that, not even for linguists, persuasive force does not result from beauty of the expression, but from the expressed scientific truth ${ }^{5}$, A. Philippide conceives and conducts his activity from a rigorously scientific perspective, refusing to issue value judgments starting from suppositions or intuitions-unlike Hasdeu, for example-, and building his discourse based on a read and appropriated bibliography, considering that any affirmation must be supported by scientific evidence. Hence, his works are attempts to find and discover the truth, based on the consultation of a huge quantity of bibliographic sources, diverse to exhaustiveness, and those, verified. In this context, the scientific polemic in the writings of A. Philippide is incorporated in the scientific discourse, as a form of action targeting the observance of the scientific truth, of the ways of edification of the scientific discourse, towards countering false erudition-encountered in numerous contemporaries-, rejection of non-value reflected at the level of certain writings (but also at the language level, where the abuse of neologisms took place, abounding in various ways of expression).

The polemic in A. Philippide's texts, thus, has two important causes: a) the need to record the scientific truth, by countering with solid arguments the erroneous scientific opinions issued by the foreign and Romanian linguists (for example, the A. Philippide - Meyer-Lübke polemic in Originea rominilor); b) personal dissatisfaction with the Romanian scientists, whose linguistic truths were the fruit of intuitions and suppositions, and by no means of thorough scientific research (for example, the A. Philippide Hasdeu polemic) ${ }^{6}$. For A. Philippide, scientific polemic represents an internal dialogue, a "dialogued polyphony" (Vlad, 2011, p. 198), an interactional dimension, determining the co-presence of more voices in "conflict". His discourse falls within a relation to the other and functions as a hypothetical antagonist, hence the polemic element could be considered as a virtual priority.

Polemicist by temper, A. Philippide has developed his critical spirit over time and often even turned against his former collaborators, such as Titu Maiorescu and Ioan Bogdan, because of a eulogistic review of the work Histoire de la langue roumaine, by Ovid Densusianu. The intentional exaggeration of form and the deep changes in the country's public life determined the accentuation of the temperamental trait of excess for young A. Philippide, also obvious in some of his articles: Idealuri, Specialistul român. Contribuție la istoriea culturii românești din secolul XIX, Pseudoștiință contemporană, etc. In 1892, in the article Idealuri, A. Philippide polemizes with Constantin Dobrogeanu-Gherea, because the latter used to impose writers progressive social-political ideals, criticizing the Junimea cultural-literary society. A. Philippide defends the Junimea conception about art and highlights its merits for the development of Romanian

\footnotetext{
5 "Persuasion is obtained by the clarification and distinction of ideas, not by adorning speech." (Wald, 1986, p. 64).

${ }^{6}$ The necessity of the critical spirit in linguistics is also supported, later, by the critic Dimitrie Macrea: "In an era in which, in the development of our language, numerous exaggerated tendencies were manifested: latinism, italianism, purism, infiltration of German and French words, drunkenness of words, Caţavencu style in oratory, the action of a lucid and merciless critical spirit and a scientific guidance against these manifestations was necessarily required.” (Macrea, 1978, p. 414).
} 
culture: “《Junimea», with the beginnings of literary activity emerging from its midst, was a modest and alluring light: too bad that on the path it decided, namely on the path of serious work, the younger rest of us couldn't all take the work forward. [...] This is why not enough light came out of the «Junimea» circle, so that it could blind a man like Mr Gherea. «Junimea» was so good that it did not inflate as the frog in the fable, it understood that in the circumstances we have been living since 1848 onwards, surrounded and overwhelmed by the products of the western intelligence, we can hope for a national literature, only when we firstly have given an account of the value of those products" (Philippide, 1892, p. 156-158). The article published by A. Philippide in "Convorbiri literare" continues with the description of the state of affairs of the 19th society and culture, defending the Junimea critical spirit: "We have no ideals because we dared to say the honest truth to people, we named the fool a fool, even if he was Romanian, and were the first to start breaking the mask of praises and pseudo-patriotic swells, all started from ideals under which the emptiness of the mind and the rottenness of the soul hide..." (Philippide, 1892, p. 155).

After a period of collaboration with "Convorbiri literare", A. Philippide found himself in Garabet Ibrăileanu's program at "Viața românească" and started to publish his polemic articles in the pages of this magazine. "Viaţa românească" did not follow a rigid populist program, and its merit consisted in the strife to promote a realistic literature, with a popular and national character, having in the middle the peasant and his fights for survival, without being the screen for any political ambitions. Therefore, A. Philippide will publish his articles Cum se apără specialistul român, Dicționarul Academiei sau basmul cucoșului roș, Un specialist român la Lipsca, Coincidențe și Prejudiții, all with reference either to the semiculture of the people of his time, with whom he felt he had nothing in common, either to the defence of the national specificity. His double nature is also emphasized by Carmen-Gabriela Pamfil, in the biography dedicated to the linguist from Iasi: "Philippide evaluated the Romanian society... with the harshness and detachment of the misfit and, concurrently, with the commitment born of too much love of the native preoccupied by its destiny" (Pamfil, 2008, p. 22). Another common point of the two men of culture, A. Philippide and Ibrăileanu, was constituted by the rejection of cosmopolitism and Romanian servitude before all Western cultural models. Although the linguist from Iasi was trained in German schools, he chose to stay in Romania to change the path of Romanian culture and maintained a correspondence with his only foreign friend, Hermann Suchier. The linguist from Iasi, A. Philippide, adheres to both directions supported by Junimea and "Convorbiri literare", respectively, by "Viața românească", because, over time, he found himself in each of the two doctrines: at Junimea by his critical spirit, political conservatism, the theory of form without substance, practicing positivism ${ }^{7}$, and in Ibrăileanu's magazine, by populism, the literary current around the magazine, which deplored the fate of the Romanian Peasant.

Linguistic theories formulated over time suffer modifications, on one hand due to the evolution of the language, on the other hand because of the ignorance of those who issued them. Indignant that they were contradicted, the latter resort to humiliating answers, insulting and offending, hiding the ignorance behind a false superiority or beyond a faulty language. for example, Gustav Weigand, on the cover of Principii de istoria limbii (1894), A. Philippide's work, writes assessments such as "stupidity", "ridiculous" or "fantastic", without offering any arguments to support his assessments, although the reviews of the great people of the era (W. Meyer-Lübke, Hermann Suchier etc.) are full of praise ${ }^{8}$, while Bogdan Petriceicu Hasdeu composes an article entitled Philippidiotisms. In what regards the linguist from Iași, A. Philippide, he does not seek to prove that he is always right, but to find the scientific truth, therefore he makes every effort to research, in order to reflect and only then to express a fair judgment, since veritas est in puteo 9 .

\footnotetext{
${ }^{7}$ A. Philippide appears to be an adept of philosophical positivism in his work Principii de istoria limbii (1894).

${ }^{8}$ W. Meyer-Lübke writes: “The work is an excellent introduction to the study of languages. [...] it required not only a replacement of the German examples with Romanian ones, but a complete skilfulness, processing and original transformation of the material offered by a predecessor. "And Hermann Suchier adds: "A primary merit of the book lies in the numerous examples, which give the author the opportunity to show the profound knowledge of the Romanian language he possesses, of its history, literature and dialects and to explain thus a lot of phenomena. " (apud Grammaticus, 1907, p. 368-369).

9"The truth is buried in the depths" (Democritus).
} 
He relies on the accuracy of the power of judgment with which he formulated his hypotheses, taking into account that "instruction potentiates the innate powers of the mind" (Horace).

If for Titu Maiorescu, the mentor of Junimea, polemic represents and intellectual parade, erudition and sophisticated expression, at A. Philippide we notice the clumsiness of expression, and the texts abound in scientific information, becoming hard to go over and understand. For A. Philippide everything is veridical, thought, calculated, and without intuitions: "Clear mind, superior intelligence, researcher with a patience and a power to work that amazes, for him nothing seems hard or impossible, when it comes to unravelling a philological problem. [...] Few are those who embody with such zeal the love for scientific truth, and even fewer those who indisputably and axiomatically solve the hard problems in such a vast and, especially in our country, so little seriously exploited field, such as philology" (Dafin, 1927, p. 96). For that matter, A. Philippide himself confesses: "Outside truth there is no use. Hence [...] all your work, all your endeavours are thrown in the wind, as long as none, the taste to show yourself more than you really are, would cloud your mind with its mists. Humble yourself therefore, don't be a Pharisee, nor a liar, here is the target towards which you need to head before all" (Philippide, 1892, p. 153).

Regarding the actual argumentation, the ad hominem argument is a major issue in the relations between polemic and rhetoric. Its qualification depends, of course, on the adopted perspective. In a normative perspective, ad hominem is not clearly an argument, but the paradigm of fault in relation to a normal, ethical and logical practice of argumentation and controversy. It allows thus the going over the spectrum that extends from the rational replica of the object to the replica (be it an insult or injury) that targets the exclusion of the person. A. Philippide resorts to personal attack to justify information spread intentionally erroneous: "And then things are not so, but entirely different. Mr Puscariu is writing today the Academy's dictionary, because none other wished to write it, and that other is me" (Philippide, 1908, p. 21), in order to emphasize the disparity between essence and appearance identified in the texts of certain linguists: the mistakes in Tiktin's ${ }^{10}$ dictionary are based on "the poverty of material, on the poverty of examples, available to the author and which he tries to hide under the appearance of a man, who doesn't even know what to do with the multitude of material available to him. [...] Meaning that Tiktin had no evidence, he took one of the two of Hasdeu, without quoting Hasdeu, passed it as his own, as if he would have found it in Dosoteiu's psalter, Academy edition, but he forgot that Hasdeu quotes the leafs, and he quotes the pages or the psalm no., and he was caught with the... steal, because this is called a steal, plagiarism." (Philippide, 1907, p. 48-50) and in order to point with the finger at the lie: "The reader will say that, if Mr Hasdeu reached page 119 with his reading, he must have read the 118 previous pages. Well, the reader is wrong. Mr Hasdeu didn't read Sievers, nor any of the authors recorded with care in the bibliographic note and quoted when here when there. Mr Hadeu knows nothing of the physiology of sounds" (Philippide, 1907, p. 74).

In his intention to shed light on the incorrectly issued linguistic theories, often an ingrate situation, the polemicist A. Philippide proves critical spirit, diachronic perspective and the desire to correct, characteristics captured by G. Calinescu, in a short dialogue: "- Are you going to tell the truth, to affirm what is good and what is bad?/ - Yes!/ - Then you are a lost man. [...] Because all those about which you tell an unfavourable truth shall say you «curse» them. [...] They will slander you that you attack out of personal enmities, will look to discredit you in the eyes of the public and will manage to create an unfavourable atmosphere for you./ - I am not afraid of insults, or of silence. Who stands beside the truth can't not win. For slowly, as new generations rise, false values disappear and you find yourself suddenly free of old enemies” (Călinescu, 1988, p. 99-101).

\section{Un specialist român la Lipsca}

The study Un specialist român la Lipsca presents a critical discourse which abounds in elements of expressivity, characteristic for the text originated in the moods of the speaking subject. The linguistic text

\footnotetext{
${ }^{10} \mathrm{He}$ is referring toRumänisch-deutsches Wörterbuch, I. A-C, Bukarest, 1895.
} 
reflects the reaction of the transmitter to the subject matter and his relation to the aesthetic dimension of language: A. Philippide is outraged by the linguistic aberrations set out by Gustav Weigand, professor at the University in Leipzig, and, at the same time, vexed by the strong support a foreign linguist, pseudospecialist of Romanian language, has from the Romanian state, while the Romanian scientists are not encouraged (see Dumistrăcel, 2009, p. 27-42). Thus, one of the functions of the text is the expressive one, because it underlines the perspective of intellectual and affective individuality, but also of the transmitter's manifestation. Combination in the syntagmatic plan of the text, as an operation of written or verbal communication, also underlines the attitude of the transmitter, since, "who speaks communicates and communicates himself” (Tudor Vianu): categorical confutation, respectively, indignation - Impossible! (Philippide, 1909, p. 25), irony, by the use of the adjectival attribute found in inversion, fine - "Ce fine observații! «muldare» după «căldare»!" “"What fine observations! «muldare» after «căldare»!") (p. 10), surprise and contemptuous rejection of the sayings of Gustav Weigand - "God forbid!" (p. 38), despise - "A mockery and nothing else!" (p. 64), determination and rejection by the use of the negative adverb no in exclamatory form - No! (p. 35), or by anti-phrase - "Has a fine sense for languages Mr Weigand!" (p. 64), "Mr Weigand loves the Romanian people! Such happiness. [...] As if it were about Napoleon, the Emperor!” (p. 158).

Linguistic grievances also target Romanian scientists, such as Sextil Pușcariu, whom A. Philippide reproaches the lack of precision in formulating sentences that he adopts or the manner in which he understands to defend them, as well as the eventual contradictions between his various stand takings: "As Mr Pușcariu disposes arbitrarily in the field of popular Latin, so he invents all sorts of things he needs, words, suffixes, phonetisms, just as arbitrarily he proceeds on the field of Romanian. The change of $k, g, t$, $d$, followed by $\breve{i}$ (consonant $i$ ) in $t s, t \check{s}, d z, d \check{z}$ is an ante-Romanian change, it took place in popular Latin. In Romanian the sounds $k, g, t, d$, if they were ever found again in contact with a following $\breve{i}$, remained $k$, $g, t, d$ and were no longer transformed in $t s, t \xi, d z, d z$. Mr Puscariu doesn't want to take account of this" (Philippide, 1909, p. 123).

A. Philippide, the scholar, impressed by the accuracy with which he captured the scientific truth and by the courage to tear apart the imposture and falsehood encountered in men of culture. The ethos elements of the adversaries, invoked in his argumentations, are not revealed to discredit Romanian or foreign linguists and to raise himself, but for the emphasis of a moral state, a lack of education, certain negative human traits, characteristic for the "specialists" of his time, for the denudation of the facts. The study Un specialist român la Lipsca comprises small portrait elements of the German linguist Gustav Weigand, realized by A. Philippide: “[...] the professor from civilized Leipzig wants to shackle the free thought of a man for personal revenge, and secretly, by letters and intrigues. No behaviour more beautiful. [...] But $\mathrm{Mr}$ Weigand swears at people and this made me extremely irritated. Harsh words as shameless, stupid flow from his mouth. [...] Mr Weigand should stay away, as of fire, of giving people epithets such as-I am ashamed that I have to mention them-stupid, or shameless, or miserable" (Philippide, 1909, p. 159160). The places, temporality and ethos of the protagonists are not simple "circumstances", but are an integral part of the polemic strategies, whose objective is reducing the adversary to silence and ridiculing him at any cost. The dialogue established between linguists brings elements of irony, humour and satire from the linguist from Iași: "I would suggest in the honour of Mr Weigand, who amused us so far and will amuse us further, to introduce for this meaning the word «vaigindesc» (Weigand's). This word has several advantages. Firstly, it will be put in the group of the word «gîndesc» (in Romanian «think»), so its conjugation presents no difficulty. Then, it reminds us of $\mathrm{Mr}$ Weigand. Finally, it also forms a pun, «vai, gîndeşte! » (in Romanian «oh my, think!»), which pun is very appropriate from all points of view" (Philippide, 1909, p. 50).

Therefore, A. Philippide enters into a confrontation with the "specialist" linguist in order to know the scientific truth and the ways of further clarification. Interpreted as a path to the truth, irony is one of A. Philippide's "weapons", and the speaker resorts to ironic remarks based on the text subjected to analysis or in the title chosen by him. For example, the polite pronoun $D$-sale (Esquire) captures the ironic attitude 
of the transmitter, depreciative manifestation reinforced by the use of the pre-posed adjective "so-called" ("[Weigand] mangles our language in His Esquire's so-called Romanian grammar").

Expressivity is a manifestation of the affective, ironic component, determined by the superficiality of the "specialists" contemporary with A. Philippide. The maximum degree of expressivity of the message is reached by the use of the affective interjection $o b$ my!: "Oh my, what a nuisance! To have a mind like children in primary classes in a discussion of grammatical analysis with a university professor from Leipzig!" (Philippide, 1909, p. 60). By the use of the volitional interjection ia (let's), A. Philippide urges to a certain attitude, of revealing the truth: "Then let's sit and talk for a little while" (p. 5). Assertive exclamatory statements are doubled by rhetorical interrogations, from the desire to impose the reader a certain point of view and to make him a partaker in a certain manner of considering the problem at hand. Dissatisfied with Weigand's linguistic discoveries in the Romanian language, A. Philippide rejects them with sarcasm or with amazement: "Who doesn't know that the final «m» has already fallen since popular Latin?” (p. 20), „Or where would Mr Weigand find «veaia» any longer?” (p. 25), "How could Mr Weigand think of such a thing?” (p. 32), "What does this jumble mean?” (p. 32), "Doesn't by any chance Mr Weigand invent the things he needs?" (p. 25), "What is this?" (p. 36), etc. In order to be more persuasive, the linguist from Iasi takes the reader as his witness, who becomes the subject of some interrogative sentences and whom Philippide addresses directly: "Do you reckon that anyone from the high circles will believe me?” (p. 141), “Do you know what Mr Weigand says?” (p. 5), "How do you think Mr Weigand understood it?” (p. 10).

\section{Conclusions}

Ultimately a scientist, the polemicist is interested in the rigor of his demonstration, in the balance of his judgment, in the spirit of justness and in revealing the truth, optimism captured in the wise words of the chronicler: "thought shall prevail!". Therefore, one can say that A. Philippide's polemic discourse is one of ideas, not of words. Revealing the truth and eliminating the deceitful, unjust ideas, determine a cultural evolution: "Easy or not, criticism was and will remain a necessary work in the public life of one nation. Understanding the wrong is a part of becoming right (Maiorescu, 1984, p. 105).

In a certain sense, A. Philippide was an idealist, and his idealism was severely challenged by the turmoil of the political life of his time. Between his opinion about the manner in which a society must function and the reality of the time he lived in was a great difference, the result being the contempt and the visible isolation from the world. Categorical evidence of his orientation towards a cultural life is shown by his non-involvement in militant politics, unlike Hasdeu, Titu Maiorescu, Sextil Puscariu or Ovid Densusianu, whose scientific activity was closely related to the issues of that time: "Alexandru Philippide had a reduced civic activity. He was the type of scholar absorbed by the research work, solitary and not very communicative. This situation is illustrated, among others, by the fact that since 1914 and until his death he never left Iași again. Since then he never took part in the Academy sessions, whose permanent member he was ever since 1900" (Macrea, 1978, p. 195). A. Philippide made up a life ideal for himself, for him "truth, justice, honour and other notions similar from an ethical point of view were a type of entities with real, sort of actual, existence, just as so many material, palpable notions, that can be noticed and known with all accuracy and precision, thanks to their materiality. [...] He himself wearied himself to conform, up to the last possible limits, to these elements which composed the real man and he was convinced that he does conform. At the same time, he also demanded from his fellowmen, considered either individuals, or in group, to do the same thing" (Iordan, 1969, p. 26).

Consequently, no matter whether we try to eliminate it, to hide behind a fictive obviousness, as if everything would work by itself, or, on the contrary, no matter whether we display it on stage ostentatiously with strategic purposes, polemic remains, at least in latent state, in the centre of any scientific endeavour. This is why to neglect its pertinence never has any other effect than to mask, even to reject the essential idea according to which at the foundation of any polemic discourse is a cause for winning, an adversary 
who must be taken out of the game through arguments which must be contested and through an audience which needs to be convinced of the superiority of a vision of the world entered in a hierarchy of values and preferences.

\section{Bibliography}

Andriescu, Al. (1983). Actualitatea lui Alexandru Philippide, in Alexandru Philippide: 50 de ani de la moarte, Iaşi.

Călinescu, G. (1988). Însemnări ş̧ polemici, Minerva Publishing House, Bucharest.

Dafin, I. (1927). Figuri ieşene, $2^{\text {nd }}$ edition, Viaţa Românească Publishing House, Iaşi.

Dumistrăcel, S. (2009). Alexandru Philippide - Gustav Weigand: ipostaze, in "Philologica Jassyensia”, year V, no 1 (9), p. $27-42$.

Gafton, Al. (2007). Polemica ştiințifică la G. Ivănescu, in "Analele Ştiiințifice ale Universității «Alexandru Ioan Cuza», din Iaş", seria III. Lingvistică, t. LIII, homage volume Vasile Arvinte, p. 475-483.

Gafton, Al. (2009). «Originea rominilor» - piatră de temelie a Şcolii lingvistice de la Iaşi, in "Philologica Jassyensia”, year V, no $1(9)$, p. $51-55$.

George, Al. (1973). La sfirrşitul lecturii, vol. I-III, Cartea Românească Publishing House, Bucharest.

Grammaticus (1907). „Adevărurile d-lui Puşcariu”, in “Viața românească, no 2, year II, p. 368-372.

Iordan, I. (1969). Alexandru I. Philippide, Editura Ştiinţifică, Bucharest.

Iordan, I. (coord.) (1978). Istoria lingvisticii româneşti, Editura Ştiințifică şi Enciclopedică, Bucharest.

Irimia, D. (1999). Introducere in stilistică, Polirom Publishing House, Iaşi.

Ivănescu, Gh. (1984). Alexandru Philippide - teoretician al limbajului, in the volume Opere alese. Teoria limbii, edition by G. Ivănescu and Carmen-Gabriela Pamfil, Editura Academiei Române, Bucharest.

Kerbrat-Orecchioni, C. (1980). La polémique et ses défnitions, in Le discours polémique, Presses Universitaires de Lyon, Lyon. Lesovici, M.D. (1999). Ironia. Ipostaze in poezia română contemporană, preface by Liviu Leonte, Institutul European, Iaşi.

Macrea, D. (1978). Contribuții la istoria lingvisticii şi filologiei româneşti, Editura Ştiințifică şi Enciclopedică, Bucharest.

Maiorescu, T. (1984). Observări polemice (1869), în Critice, volume I, Editura Minerva, Bucharest.

Pamfil, C.-G. (2008). Alexandru Philippide, Editura Litera Internaţional, Bucharest-Chişinău.

Philippide, Al. (1892). Idealuri, in "Convorbiri literare", XXV, no 11-12, p. 1015-1023; XXVII, no 4, p. 289-320.

Philippide, Al. (1894). Istoria limbii române, I. Principii de istoria limbii, Tipografia Naţională, Iaşi.

Philippide, Al. (1907). Specialistul român. Contribuție la istoriea culturii românești din secolul XIX, Editura "Vieții românești", Iaşi.

Philippide, Al. (1908). Cum se apără specialistul român, în "Viaţa românească", III, volume VIII, no 2, p. 16-28.

Philippide, Al. (1909). Un specialist român la Lipsca, Tipografia Dacia P.\&D. Iliescu, Iaşi.

Philippide, Al. (1928). Originea rominnilor, II. Ce spun limbile romînă și albaneză, Tipografia "Viața românească” S.A., Iași.

Philippide, Al. (2006). Ştiința noastră. Cum ştim. Cum ar trebui să ştim. Starea psicologică. Manuscript found at the Library of the Iaşi bsidiary of the Romanian Academy, Alexandru I. Philippide fund. The document was edited by G. Ivănescu and Carmen-Gabriela Pamfil, with an afterword by Al. Andriescu, in "Analele Universității «Ştefan cel Mare» Suceava", Philology Series, A. Linguistics, XII, 2006, no 1.

Plantin, Chr. (2003). Des polémistes aux polémiqueurs, in La parole polémique, by Gilles Declerq, Michel Murat, Jacqueline Dangel, Honoré Champion, Paris.

Schopenhauer, A. (2012), Arta de a avea intotdeauna dreptate sau Dialectica eristică, established text, translation from German, foreword and notes by Gabriel H. Decuble, Editura Art, Bucharest.

Vlad, D. (2011). La polémique entre scientifiques: une approche polyphonique, in "Studii de lingvistică", no 1, p. 197-212.

Wald, H. (1986). Expresivitatea ideilor, Editura Cartea Românească. 